\title{
New record for the distribution of the colonial hydroid Cordylophora caspia (Pallas, 1771) (Cnidaria: Hydrozoa) in Argentina
}

\author{
María I. Deserti*, Alicia H. Escalante and Fabián H. Acuña
}

Universidad Nacional de Mar del Plata (UNMdP), Instituto de Investigaciones Marinas y Costeras (IIMyC) - CONICET, Funes 3250. 7600 Mar del Plata, Buenos Aires, Argentina * Corresponding author. E-mail: mdeserti@mdp.edu.ar

\begin{abstract}
Cordylophora caspia is a colonial, athecate hydroid inhabiting both in freshwater and brackish habitats. Its global distribution is in part due to its ability to tolerate a wide range of salinity. It is considered an invasive species and its control is widely studied because of the industrial and ecological problems it causes in many environments. We report for the first time the occurrence of this hydrozoan in Nahuel Rucá Lake (Buenos Aires province, Argentina) with some notes on its internal and external morphology.
\end{abstract}

Key words: Hydrozoa, Cordylophora caspia, Nahuel Rucá Lake, Buenos Aires Province

Although cnidarians are mostly marine organisms, a handful of species live in nearly all types of freshwater habitats (i.e., streams, rivers, ponds and lakes) and they mainly occur in mesotrophic to eutrophic habitats (Jankowski et al. 2008). Cordylophora caspia Pallas, 1771 is a colonial, athecate hydroid occurring in freshwater to brackish habitats that tolerates a salinity range from o to $20 \mathrm{ppt}$ (Folino 2000). The genus Cordylophora was first discovered in the Caspian and Black Seas and supposedly arrived at North America in the late 18oos (Clarke 1878). Its global distribution is in part due to its ability to tolerate a wide range of salinity along with increased boat travel and ballast discharge (Roos 1979) and also anthropogenic factors such as pollution and eutrophication (Hubschman 1971). It is considered an invasive species (Roos 1979; Folino 2000; Folino-Rorem and Indelicato 2005; Meek et al. 2012) and its control is widely studied because these polyps form dense colonies causing industrial pipeline obstructions.

Cordylophora caspia is a clonal organism that also reproduces sexually, extending towards new substrates by new free-swimming planula larvae (Jormalainen et al. 1994). It is dioecius with gonophores containing eggs or sperm (Folino 2000) and medusa stage is lacking (Pennak 1989). Colonies are polymorphic with polyps specialized for feeding (gastrozooids) or reproduction (gonophores) and grow by adding more hydrants to hydrocauli on the upright branches and extending the hydrorhiza (Jormalainen et al. 1994).

Cordylophora caspia survives during unfavorable conditions and cold temperatures via spheres of coenosarcs tissue, called menonts, which remain in the perisarc of the hydrocauli and regenerate when conditions are restored (Roos 1979). This survival strategy and the ability to adapt to a wide salinity range contribute to the current large distribution of the species.

The genus has seven valid species; five of them are found in specific localities and C. caspia and C. lacustris are widely distributed (Wollschlager 2011). C. caspia has been recorded from many more or less brackish localities in Europe; it has also been found at some places in Egypt, China, the United States, Brazil, Argentina, and Australia, including Tasmania (Vervoort 1946; Zamponi 1991). The first records of the genus for Argentina were published in 1923 by Gaggero in reference to C. lacustris Allman, found in Santiago River, a tributary of Río de la Plata estuary. Ringuelet and Olivier (1954) have cited C. caspia Pallas from Chascomús and Lobos lakes, belonging to the Salado River basin. In Brazil it was recorded by Roch (1924) from Rio de Janeiro and by Cordero (1941) from Las Brujas stream in Montevideo (Uruguay). Both species are distinguished by morphological characters that are phenotypically plastic and therefore unreliable for classifications. For this reason, many taxonomists consider $C$. caspia and $C$. lacustris to be conspecific. In addition, this synonymy is also geographically justified by the co-occurrence of both species (Folino 2000).

Nahuel Rucá Lake ( $37^{\circ} 37^{\prime}$ S, $057^{\circ} 26^{\prime}$ W; o.6o m deep; 245 ha) is a shallow lake located in the southeast region of the Pampa grasslands, Buenos Aires Province, Argentina (Figure 1) and is paleoecologically associated to two sites, the Mar Chiquita coastal lagoon and Hinojales Lake, as the entire area was affected by sea level fluctuations during the Holocene (Stutz et al. 2010). Mar Chiquita coastal lagoon is orientated NE-SW and connected to the sea by an ebb channel (Merlotto and Bertola 2009); it has an area of $58 \mathrm{~km}^{2}$ and $25 \mathrm{~km}$ in length. The nearest region to the ocean has polyhaline conditions, but the opposite end is entirely composed of freshwaters (Ringuelet 1962). Nowadays, Nahuel Rucá Lake is a shallow depression basin occupied by permanent freshwaters (Stutz and Prieto 2003), the result of the development of estuarine environment and a sandy barrier to the east of the Pleistocene 
paleocliff (Stutz et al. 2010). The climate of the area is temperate, with mean annual temperature and precipitation of $13.8^{\circ} \mathrm{C}$ and $941 \mathrm{~mm}$, respectively. The plant community is characterized by several species of emergent, free floating and submersed macrophytes (Stutz et al. 2010).

One sample of the submersed macrophyte Ceratophyllum demersum was taken on 26 February 2014 as a part of an annual sampling project. The limnological parameters estimated were: water temperature $18^{\circ} \mathrm{C}$, depth $0.60 \mathrm{~m}$, transparency (Secchi) $0.30 \mathrm{~m}, \mathrm{pH} 8.1$ and dissolved oxygen $6.0 \mathrm{mg} \mathrm{O} / 1$. Two monopodial colonies (independent stolons) of $C$. caspia were observed attached to $C$. demersum (Figure 2a). A total of 23 whitish or transparent and fusiform gastrozooids were recorded. The column length oscillated from 1.21 to $3.95 \mathrm{~mm}$. The tentacles, fine and filiform, were uniformly distributed on the hydrant and range in number from 4 to 17 . Stolons were cylindrical and surrounded by brown perisarc of $0.26 \mathrm{~mm}$ in diameter. In the basis of hydrocauli we observed rings or annulations. The distance between hydrocauli was 6 to $7 \mathrm{~cm}$. Gonophores were not observed (Figure 2b, c). This hydrozoan possessed two types of nematocysts, desmoneme (with the classical form) and a second type recognized like heterotrichous microbasic eurytele, according to Mariscal (1974). The

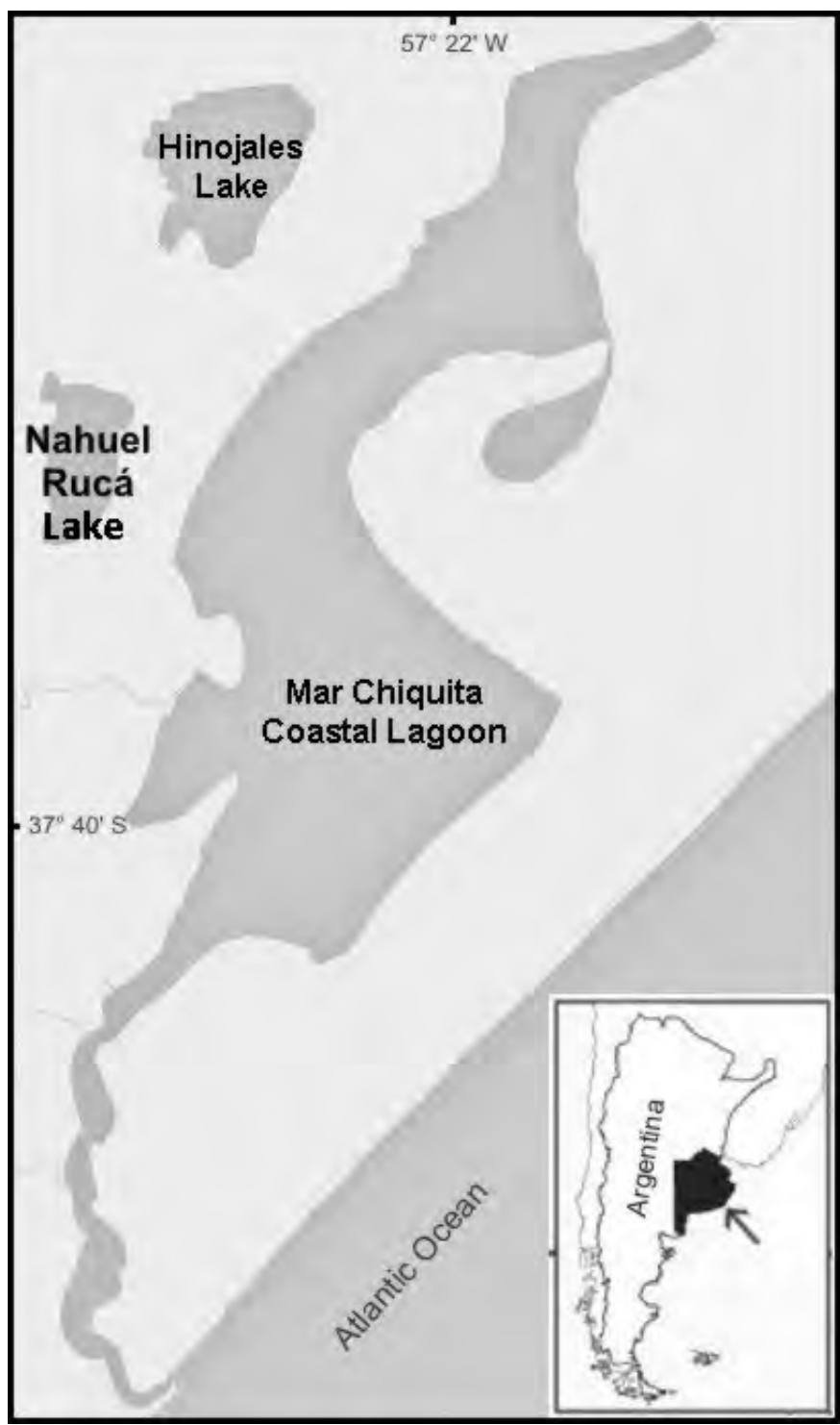

Figure 1. Map of Nahuel Rucá Lake (Buenos Aires province, Argentina). desmonemes, most abundant, were oval and smaller than eurytele. The filament gives approximately one and a half turns inside the capsule. Heterotrichous microbasic eurytele presents a short shaft, less than three times capsule length, dilated distally and with spines of unequal size. The filament is fine, long and helical (Figure 3a, b). Table 1 shows the measurements of each type. After 20 days, all hydrants had died and in one stolon it could be observed one menont with 12.5 $\mu \mathrm{m}$ in diameter (Figure $3 \mathrm{c}$ ). Similarly to Gaggero (1923) and Ringuelet and Olivier (1954), we also found attached to perisarc many ciliates and diatoms.
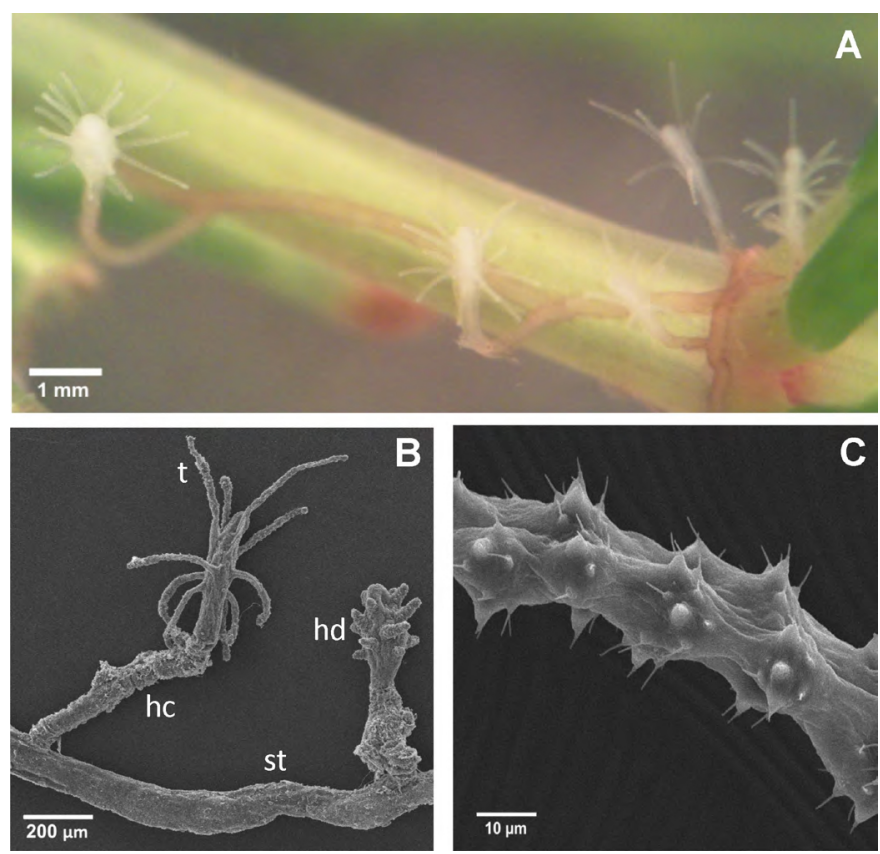

Figure 2. A, colony of Cordylophora caspia attached to Ceratophyllum demersum. B, SEM of two hydrants (expanded and contracted) of Cordylophora caspia. C, SEM of cnidocyst arrangement in tentacle. Abbreviations: $\mathrm{t}$, tentacles; hc, hidrocauli with rings or annuli; hd, hydrant; st, stolon.

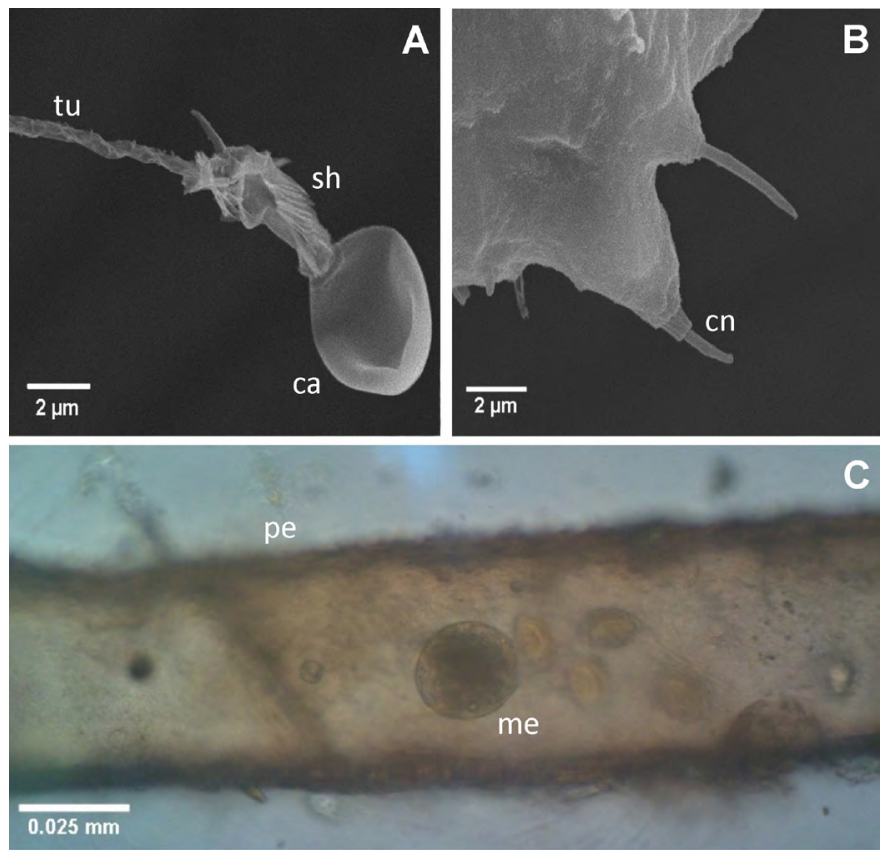

Figure 3. A, fired heterotrichous microbasic eurytele. B, cnidocil detail. C, menont detail. Abbreviations: tu, tubule; sh, shaft with unequal spines; $\mathrm{Ca}$, capsule; cn, cnidocil; pe, perisarc; me, menonts. 
How this emblematic species gained access to this wetland is unknown as well as the knowledge of the natural history of this genus in the region. It seems likely that $C$. caspia has reached Nahuel Rucá Lake by any type of transportation, including natural vectors such as birds. This finding is important to understand the expansion or invasion of $C$. caspia in this region and to understand future impacts on native communities of estuarine and freshwater ecosystems.

\section{ACKNOWLEDGMENTS}

We thank Dr. Mauricio Zamponi (UNMdP-CONICET, mozamponi@gmail.com) for the identification of the material; the staff of the Laboratory of Parasitology (National University of Mar del Plata) for providing the transportation to the study site. This work was funded by grant EXA 648/14 to FHA. This work is part of the doctoral thesis of MID.

\section{LITERATURE CITED}

Clarke, S.F. 1878. A new locality for Cordylophora. The American Naturalist 12(4): 232-234 (http://www.jstor.org/stable/2463785).

Cordero, E.H.1941. Observaciones sobre algunas especies sudamericanas del género Hydra. II. Hydra y Cordylophora en el Uruguay. Anais de Academia Brasileira de Ciencias 13(3): 173-183.

Folino, N.C. 200o. The freshwater expansion and classification of the colonial hydroid Cordylophora (Phylum Cnidaria, Class Hydrozoa); pp 139-144 in: J. Pederson (ed.) Marine Bioinvasions: Proceedings of the First National Conference, January 24-27, 1999. Cambridge: Massachusetts Institute of Technology Sea Grant College Program.

Folino-Rorem, N.C. and J. Indelicato. 2005. Controlling biofouling caused by the colonial hydroid Cordylophora caspia. Water Research 39(12): 2731-2737 (doi: 10.1016/j.watres.2005.04.053).

Gaggero, P. 1923. Cordylophora lacustris Allman en el Río de La Plata. Anales de la Sociedad Científica Argentina 36: 264-268.

Hubschman, J.H. 1971. Lake Erie; pollution abatement then what? Science 171(3971): 536-540 (doi: 10.1126/science.171.3971.536).

Janowski, T., A.G. Collins and R. Campbell. 2008. Global diversity of inland water cnidarians. Hydrobiologia 595: 35-40 (doi: 10.1007/ s10750-007-9001-9)

Jormalainen, V., T. Honkanen, T. Vuorisalo and P. Laihonen. 1994. Growth and reproduction of an estuarine population of colonial hydroid Cordylophora caspia (Pallas) in the northern Baltic Sea. Helgolander Meeresunters 48(4): 407-418 (doi: 10.1007/BFo2366254).

Mariscal, R.N. 1974. Nematocysts; pp. 129-178, in: L. Muscatine and H.M. Lenhoff (eds.) Coelenterate Biology. New York: Academic Press.

Meek, M.H., A.P. Wintzer, W.C. Wetzel and B. May. 2012. Climate change likely to facilitate the invasion of the non-native hydroid, Cordylophora caspia, in the San Francisco estuary. PLoS ONE 7(10): e46373 (doi: 10.1371/journal.pone.0046373).

Merlotto, A. and G.R. Bertola. 2009. Coastline evolution at Balneario Parque Mar Chiquita, Argentina. Ciencias Marinas 35(3): 271-286 (http://www.scielo.org.mx/pdf/ciemar/v35n3/v35n3a3.pdf).

Pennak, R.W. 1989. Fresh-water Invertebrates of the United States: Protozoa to Mollusca. $3^{\text {rd }}$ edition. New York: John Wiley \& Sons. 628 pp.

Ringuelet, R. 1962. Ecología Acuática Continental. Buenos Aires:
Table 1. Statistical results for nematocysts of Cordylophora caspia. Mean and range are expressed in $\mu \mathrm{m}$.

\begin{tabular}{|c|c|c|c|c|}
\hline & \multicolumn{2}{|c|}{ Desmoneme } & \multicolumn{2}{|l|}{ Eurytele } \\
\hline & Length & Width & Length & Width \\
\hline Number & 23 & 23 & 14 & 14 \\
\hline Mean \pm st dev & $4.93 \pm 0.26$ & $2.90 \pm 0.28$ & $8.56 \pm 0.74$ & $3.87 \pm 0.34$ \\
\hline Median & 5 & 3 & 9 & 4 \\
\hline Range & $4.50-5.50$ & $2.50-3.50$ & $7-10$ & $3-4.50$ \\
\hline
\end{tabular}

Ediciones EUDEBA. 138 pp.

Ringuelet, R.A. and S.R. Olivier. 1954. Anotaciones sobre Cordylophora caspia (Pallas) en la Argentina (Hydrozoa). Notas del Museo La Plata 17 (Zool. 147): 67-70.

Roch, F. 1924. Experimentelle Untersuchungen an Cordylophora caspia (Pallas) (= lacustris A liman) über die Abhängigkeit ihrer geographischen Verbreitung und ihrer Wuchsformen von den physikalisch-ehemischen Bedingungen des urngebenden Mediums. Zeitschrift für Morphologie und Ökologie der Tiere 2: 350-426; 667-670.

Roos P.J. 1979. Two-stage life cycle of a Cordylophora population in the Netherlands. Hydrobiologia 62(3): 231-239 (doi: 10.1007/ BFooo43540).

Stutz, S. and A.R. Prieto. 2003. Modern pollen and vegetation relationships in Mar Chiquita coastal lagoon area, southeastern Pampa grasslands, Argentina. Review of Palaeobotany and Palynology 126(3-4): 183-195 (doi: 10.1016/So034-6667(03)ooo84-8).

Stutz, S., C.M. Borel, S.L. Fontana, L. del Puerto, H. Inda, F. GarcíaRodríguez and M.S. Tonello. 2010. Late Holocene climate and environment of the SE Pampa grasslands, Argentina, inferred from biological indicators in shallow, freshwater Lake Nahuel Rucá. Journal of Paleolimnology 44(3): 761-775 (doi: 10.1007/ s10933-010-9450-4).

Vervoort, W. 1946. Exotic hydroids in the collections of the Rijksmuseum van Natuurlijke Historie and the Zoological Museum at Amsterdam. Zoologische Mededeelingen Rijksmuseum van Natuurlijk e Historie te Leyden 26(12): 287-351 (http://www. repository.naturalis.nl/record/318911).

Wollschlager, J. 2011. Nematocysts of the Invasive Species Cordylophora caspia. Electronic Thesis or Dissertation. Ohio: Ohio State University, 2011. OhioLINK Electronic Theses and Dissertations Center. 48 pp. (https://etd.ohiolink.edu/!etd.send_file?accessio $\mathrm{n}=$ osu1299609133\&disposition=inline).

Zamponi, M.O. 1991. Los Cnidaria; 40: 5-51, in: de Castellanos, Z.A. (dir.). Fauna de Agua Dulce de la República Argentina. Buenos Aires: PROFADU-CONICET.

Authors' contribution statement: MID and FHA planned, write the text and the conclusions of the study. MID and AHE collected the material and measured the limnological parameters. MID and FHA performed electron microscopy protocol.

Received: August 2014

Accepted: November 2014

Editorial responsibility: Sérgio Stampar 